Article

\title{
Mapping Shoreline Changes Over the Years: The Case Study of Navarino Bay, Pylos, Messenia, Greece
}

\author{
George Malaperdas ${ }^{1, *}$, Nikolaos Panagopoulos² \\ ${ }^{1}$ Laboratory of Archaeometry, Department of History, Archaeology and Cultural Resources Management, \\ University of The Peloponnese, Kalamata, Greece. \\ 2 Department of History, Archaeology and Cultural Resources Management, University of The Peloponnese, \\ Kalamata, Greece. \\ * Correspondence: envcart@yahoo.gr
}

How to cite this paper: Malaperdas, G., \& Panagopoulos, N. (2021). Mapping Shoreline Changes Over the Years: The Case Study of Navarino Bay, Pylos, Messenia, Greece. World Journal of Geomatics and Geosciences, 1(1). DOI:

10.31586/wjgg.2021.010103. Retrieved from https://www.scipublications.com/journal/in-

dex.php/wjgg/article/view/80
Received: June 9, 2021

Accepted: July 21, 2021

Published: July 22, 2021

Copyright: (c) 2021 by the authors. Submitted for possible open access publication under the terms and conditions of the Creative Commons Attribution (CC BY) license (http://creativecommons.org/licenses /by/4.0/).

\begin{abstract}
This paper deals with the mapping of shorelines through existing maps. Its main purpose is not to give an accurate change of sea level and shoreline in general, but to give guidelines to a more general mapping of shorelines. Geographic Information System (GIS) and paleoenvironmental analysis are powerful tools for archaeology and environmental researches and contributes in such a direction. Furthermore, this essay will present an analysis of the shoreline changes and the resultant geomorphologies during the prehistoric eras, especially the Mesolithic, Neolithic, and the Helladic eras of the area. The study area which was selected concerns the west part of Messenia Prefecture in Greece. More specifically it concerns the wider area of Pylos and the Navarino bay. The Navarino bay is located near the ancient city of Pylos and the kingdom and palace of Nestor during the Mycenaean period
\end{abstract}

Keywords: GIS; Mapping Shoreline Changes; Pylos; Navarino Bay, Digitization

\section{Introduction}

Following the Last Glacial Maximum (LGM), the glacio-eustatic sea level increase resulted in worldwide flooding and the emergence of marine embayment. The significant slowdown in the mid-Holocene resulted in overcompensation by sediment yields and shoreline propagation in many regions. Many scientists have studied the coastal areas of the Eastern Mediterranean, due to the rapid geomorphological changes throw the eras, and also for archaeological interest. In this essay the case study that is examined is the southwestern part of the Peloponnese, more specifically the Navarino bay with the shallow coastal lagoon of Yialova "Osmanaga" near Pylos and the surrounding area. Geomorphologists, archaeologists, and sedimentologists have all expressed interest in the area. During the Mycenaean period, the Navarino bay was near the ancient city of Pylos, as well as the kingdom and palace of Nestor (Figure 1). Furthermore, this essay will present an analysis of the shoreline changes and the resultant geomorphologies during the prehistoric eras, especially the Mesolithic, Neolithic, and the Helladic eras of the area and the Bay of Navarino [1,2].

The region of Pylia in the southwestern Peloponnese is considered both tectonically and seismically as one of the most active areas in Greece due to the proximity of the Hellenic trench, which represent a major subduction zone. Its exhibits a composite morphotectonic structure, due to the existence of numerous small morphological units of various directions. The dominant mountains of the region is the Lykodemo $(960 \mathrm{~m})$ at the north east section which has a conical shape, and Mavrovouni $(518 \mathrm{~m})$ at the south eastern part of the area $[3,4]$. 


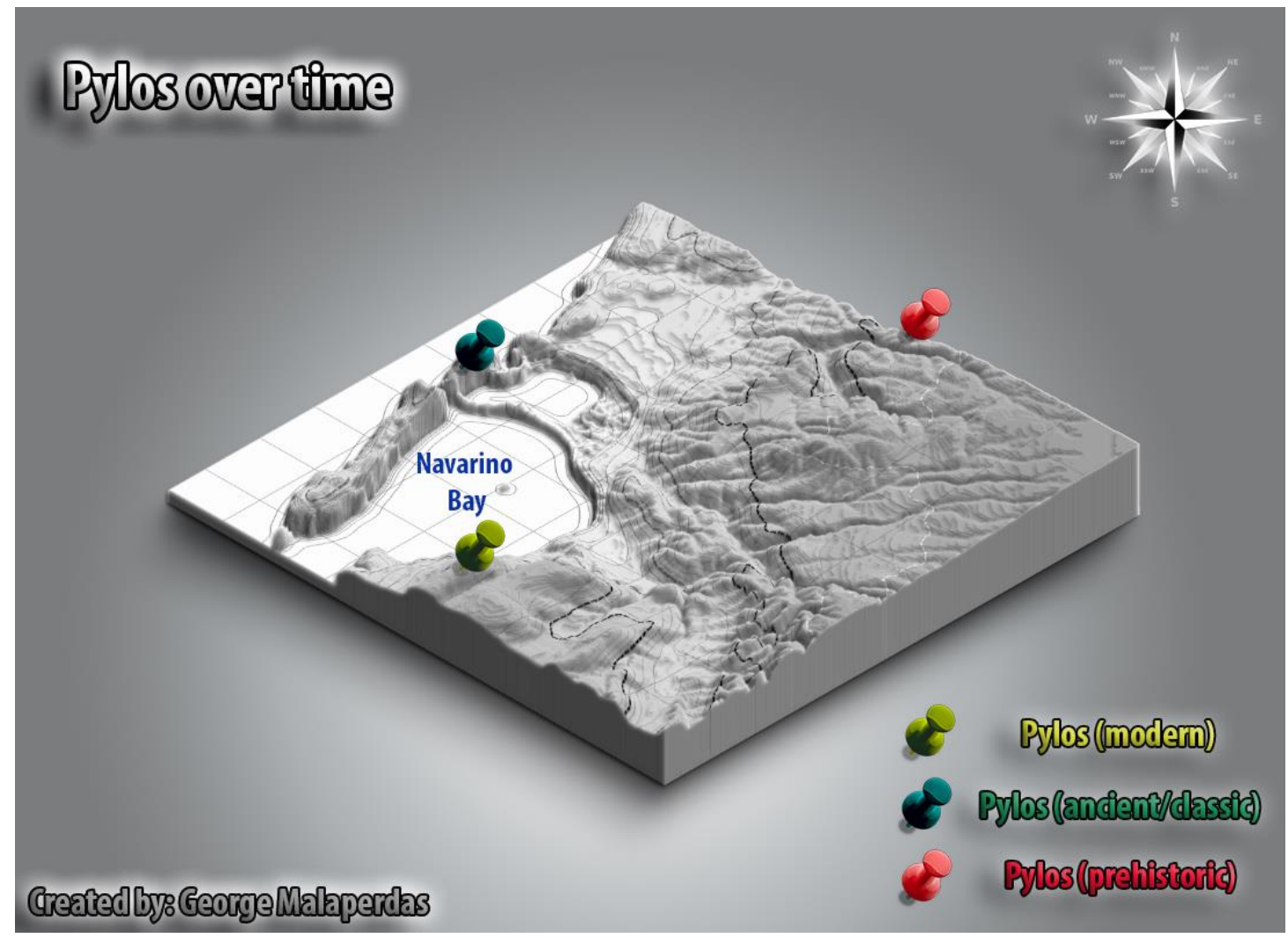

Figure 1. The different locations where Pylos was placed over the years. However, especially Pylos in prehistoric era is intertwined with the whole wider area. The placement of the red pin refers to the so-called palace of Nestor.

The Navarino embayment and the surrounding area were habited by humans during Prehistory and onward [5-7]. In the northern part of the area Bronze Age settlements have been discovered, as well as Classical, Hellenistic, and Roman sites have been identified between the Yialova Lagoon and Navarino bay [8,9]. Agriculture is intensive across the low-lying plain, which was presumably drained in the Helladic age after the Amoudheri River was diverted at the plain's northern edge [10].

\subsection{Structure of the Area}

The Navarino embayment is about $4 \mathrm{~km}$ broad and $10 \mathrm{~km}$ long, and it is located on the west side of the Messenia prefecture, along the Ionian Sea, in the southwest of Peloponnese, Greece, north of the modern town of Pylos. At the north of the embayment is the Yialova also referred as "Osmanaga" lagoon and a low-lying plain. Three narrow limestone sharp ridges from the Eocene creates a boundary between the embayment and the Ionian Sea, with the Sphakteria island being the physical boundary which drop off more than $200 \mathrm{~m}$ in depth $2 \mathrm{~km}$ west of the offshore, while the east part of the island lying sharply into the bay. The north of the bay, at the Quaternary period has been uplifted over 400 meters by Pliocene sediments and form a plain or in Greek "Kampos" with a surface of degradation to southwest. The northeastern plain was steeply fragmented by a stream's erosion, during the Quaternary period. Miocene flysch can be found in the east and southeast of the area. The terrain distorted from an Eu-Tyrrenthian (last interglacial) terrace up to $40 \mathrm{~m}$ above sea level in the region to a Neo-Tyrrhenian (last glacial interstadial) terrace roughly $4 \mathrm{~m}$ above present sea level in the coastal area due to high rates of uplifting. Navarino is a very active region of tectonic movement with an estimate subsiding of the southwest of 2 meters per thousand years, and of the northwest of 0-5 meters per thousand years. The region depression was a combination of upward, erosion, and incision of a 
deep valley into the Neogene sediments, which on the west were bordered with the limestone cliffs of the Eocene. The erosional and tectonic events took place during the glacial and interstadial stages of the late Quaternary [10].

Today morphology of Navarino is correlated to Post-Pliocene tectonic and erosionaldepositional events. Earlier Quaternary and Pliocene sediments border the shoreline to the north of "Profitis Ilias" ridge, where erosion was faster and coastal sand sediments developed a sandy beach with a shape of an arc for about $4 \mathrm{~km}$.

The depth of Navarino bay is more than 60 meters to the south end and about 40 meters $1 \mathrm{~km}$ south of the northern sand barriers. Sand barriers was developed from the wave process of the Ionian Sea, entering the bay from southwest, whereas other waves from the delta of "Xerias river" help for the creation of a sand barrier north of the bay of Navarino. The barrier is a broad arch looking northward with a wide of $4 \mathrm{~km}$ and approximately $3 \mathrm{~km}$ long and where the beach accretion is visible, while a low- lying dune field creates a slope to the north near Yialova "Osmanaga" lagoon. The sandy barrier has been sheltered since Hellenistic times, as of the existence of a Hellenistic cemetery, and other archaeological sites, as for example Roman mosaics or walls. The top of the Hellenistic cemetery is situated 2 meters below present sea level and are a clear evidence of habitation and sea level [10].

The "Yialova" or "Osmanaga" lagoon is located to the north of the barrier. Environmentally sensitive places produced behind sand and gravel barrier shorelines, at the terminal area of coastal alluvial plains, or at river mouths are known as coastal lagoons. They're shallow, with essential ecosystems that exist between the coastal and marine environments, and they might be permanently open or sporadically closed. The "Tyflomytis" alluvial plain was formed by Pliocene marls and conglomerates, and "Yialova" lagoon is located inside it. This lagoon is a typical swallow Mediterranean lagoon with a maximum depth of 1 meter, with the sediments of the lagoon having a concentration up to $50 \%$ of calcium carbonate (CaCO3). To the north, the lagoon is bordered by a low lying fluvial fertile plain, and to the east a swamp is located in the delta of the Yialova River being drained today and used for agriculture. To the west is a channel, where the waves drop off the sand sediments. This process has led to the development of a small embayment called "Voidokoilia". The lagoon was blocked off from the sea by the southern barrier, a process that may have occurred during Classical times due to the presence of sites on the barrier $[2,10]$.

The sediments pass the plain through the "Typhlomitis Creek" running from east northeast which now have been altered into an east-west channel moving the water to the "Voidokoilia" bay, in order to avoid the flooding of the lower and southern parts of the plain. The "Amoudheri River", which is located north of the "Typhlomitis Creek" and flows through a deep incised valley before changing its course to the west, via a gorge leading to the Ionian Sea, is the main source of drainage for the plain from the north and east. Scientists consider that man divert the river by cutting a gap north of Romano village and eliminate the flood problems, and increase the possibilities of habitation of the plain. Because of extensive Neogene uplift and subsidence processes, as well as local fault tectonics, today's geomorphology has evolved (Figure 2). In order to understand all these geological processes geomorphological mapping is a useful tool for reconstructing the evolution of the area $[2,10]$. 


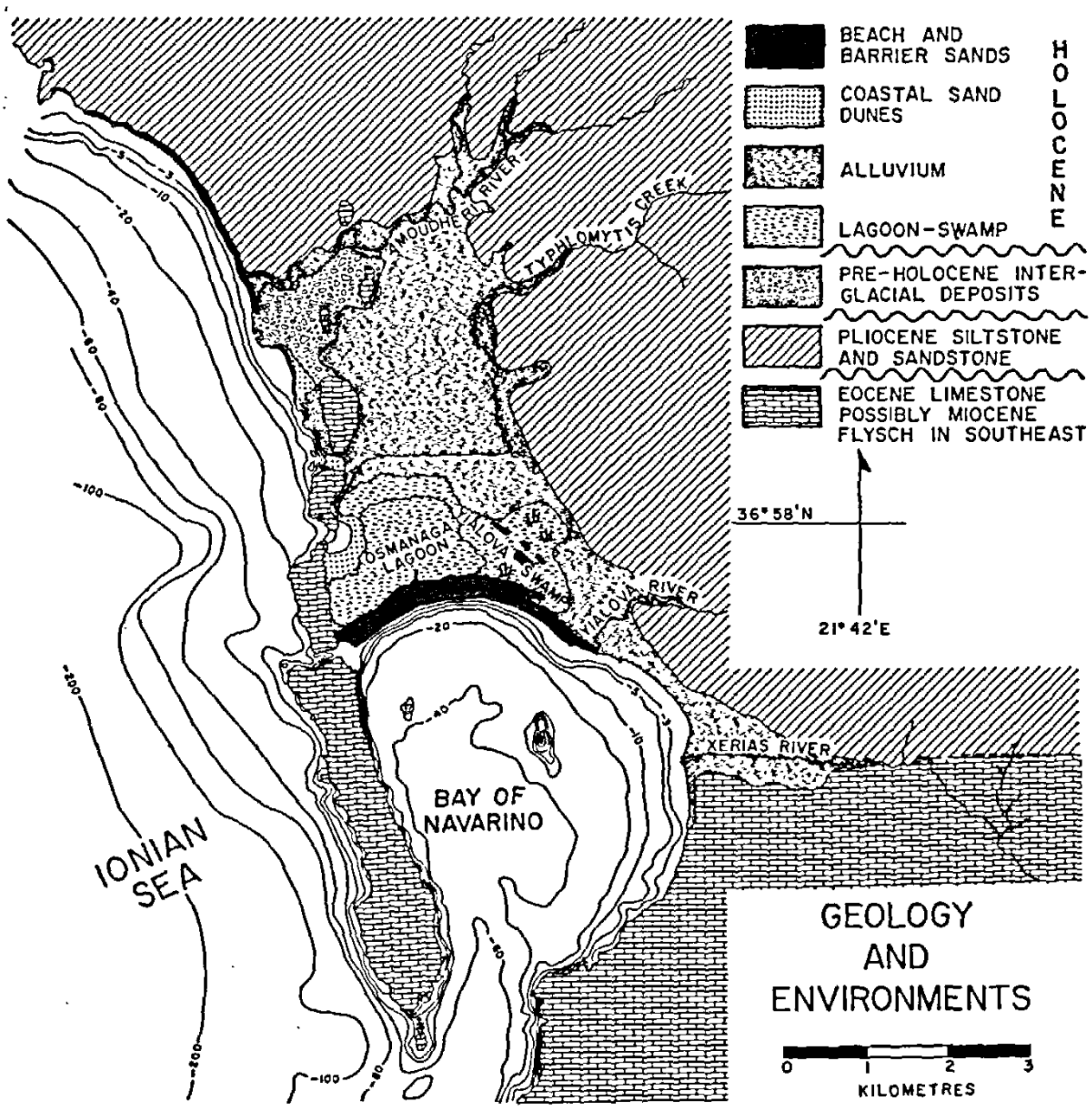
1980].

Figure 2. Geology and present sedimentary environments of the Navarino area [Source: Kraft,

\section{Materials and Methods}

Geographical mapping is a useful tool to understand and interpret the data of an area in order to reconstruct the evolution and the development of a site [11]. Geographic Information System (GIS) is a system to store, capture, manipulate, analyze, manage, and present the geographic or spatial data. It is an important tool for archaeology as it is fast, interactive and easy to operate $[12,13]$. Digitization is the most common method for the creation of data, where a topographic map is transferred into a digital through suitable software [14]. Using images from satellites, aircrafts, etc. and digitizing the data, it can be extracted into geographical $[15,16]$.

For this essay the software that was used to digitize the area of our study was the ArcGIS 10.0. The Greek Grid Reference System of 1987 (EGSA '87) coordinate system which offers a reference scale of all Greece was used. The topographic map that was digitized (Figure 3) during this study was initially published by Kraft and his team [10]. 


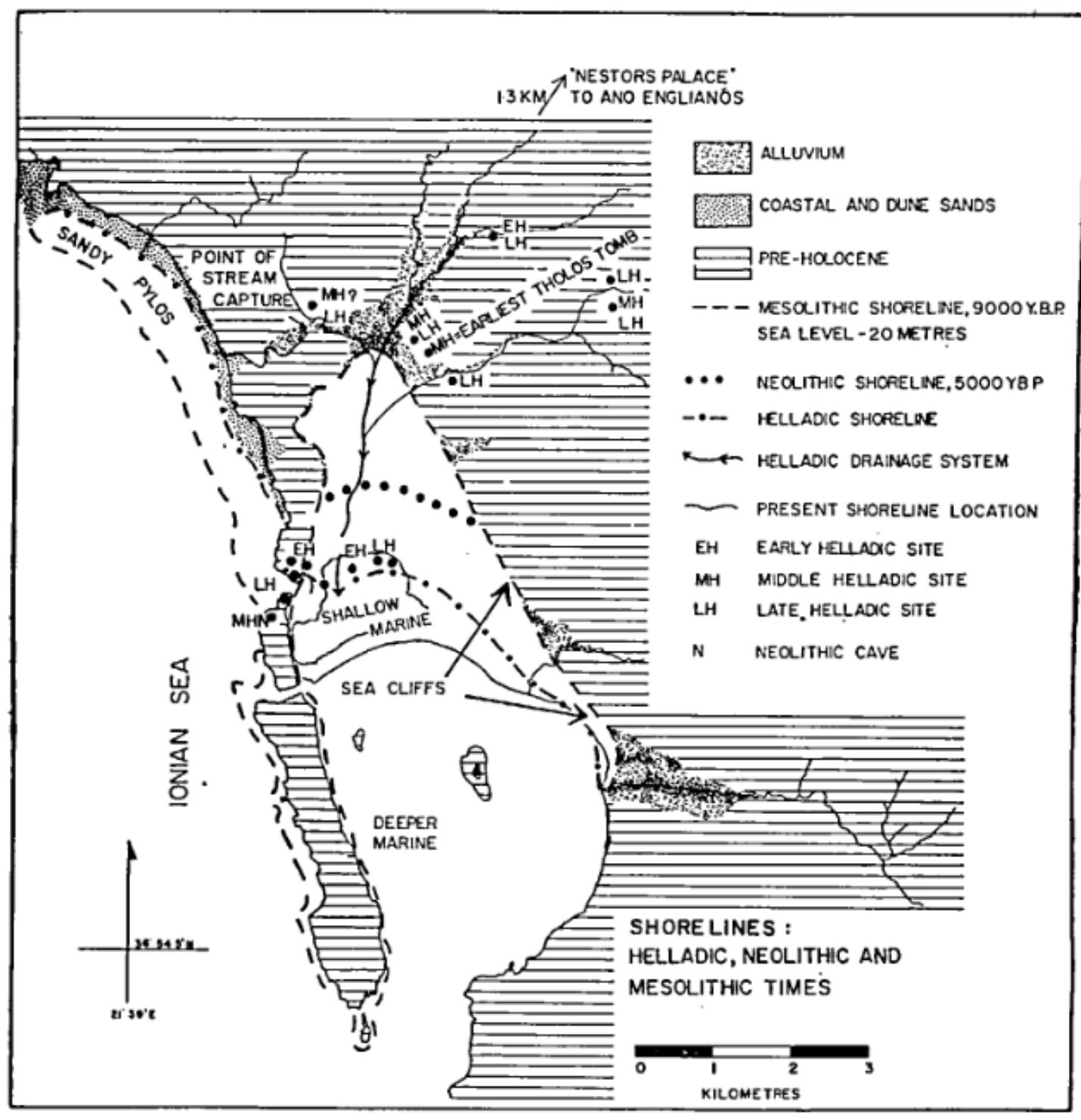

Figure 3. Shoreline changes of Navarino Bay. Late Helladic palaeogeographic reconstructions of the Navarino embayment, roughly 3500 years before the present. The map depicts known Helladic archaeological sites. Ancient sea cliffs are linked to Neolithic (5000 B.P.) and Mesolithic (9000 B.P.) shoreline reconstructions. On the north flank of Coryphasium, one neolithic site is indicated [Source: Kraft, 1980].

The shoreline of the bay of Navarino was digitized using a set of coordinate Polylines. The archaeological sites of the different historic periods were marked into the thematic map with points. The aim of this research was to present the four different phases, from Mesolithic to Present, of the shoreline of Navarino bay (Figure 4). 


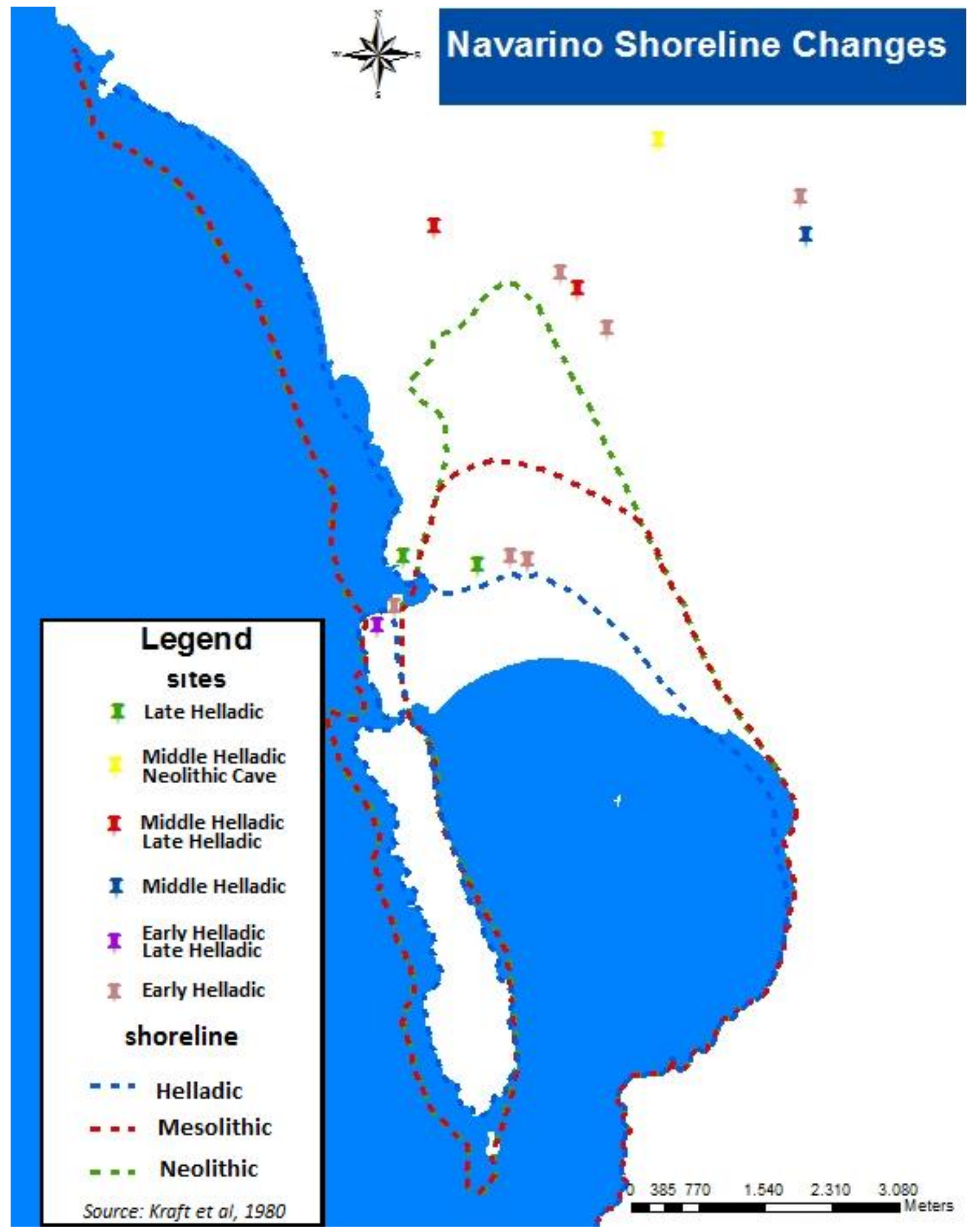

Figure 4. Shoreline changes of Navarino Bay.

The four phases of the visualized map were created using autonomous shapefiles: Mesolithic shoreline 9.000 B.C, Neolithic shoreline 5.000 BC, Helladic shoreline and Present shoreline (Figure 4). For the completion of the thematic map the following elements were added: scale, north arrow, legend and the information that was processed. Also, the title "Navarino Shoreline Changes" was given (Figure 5). 

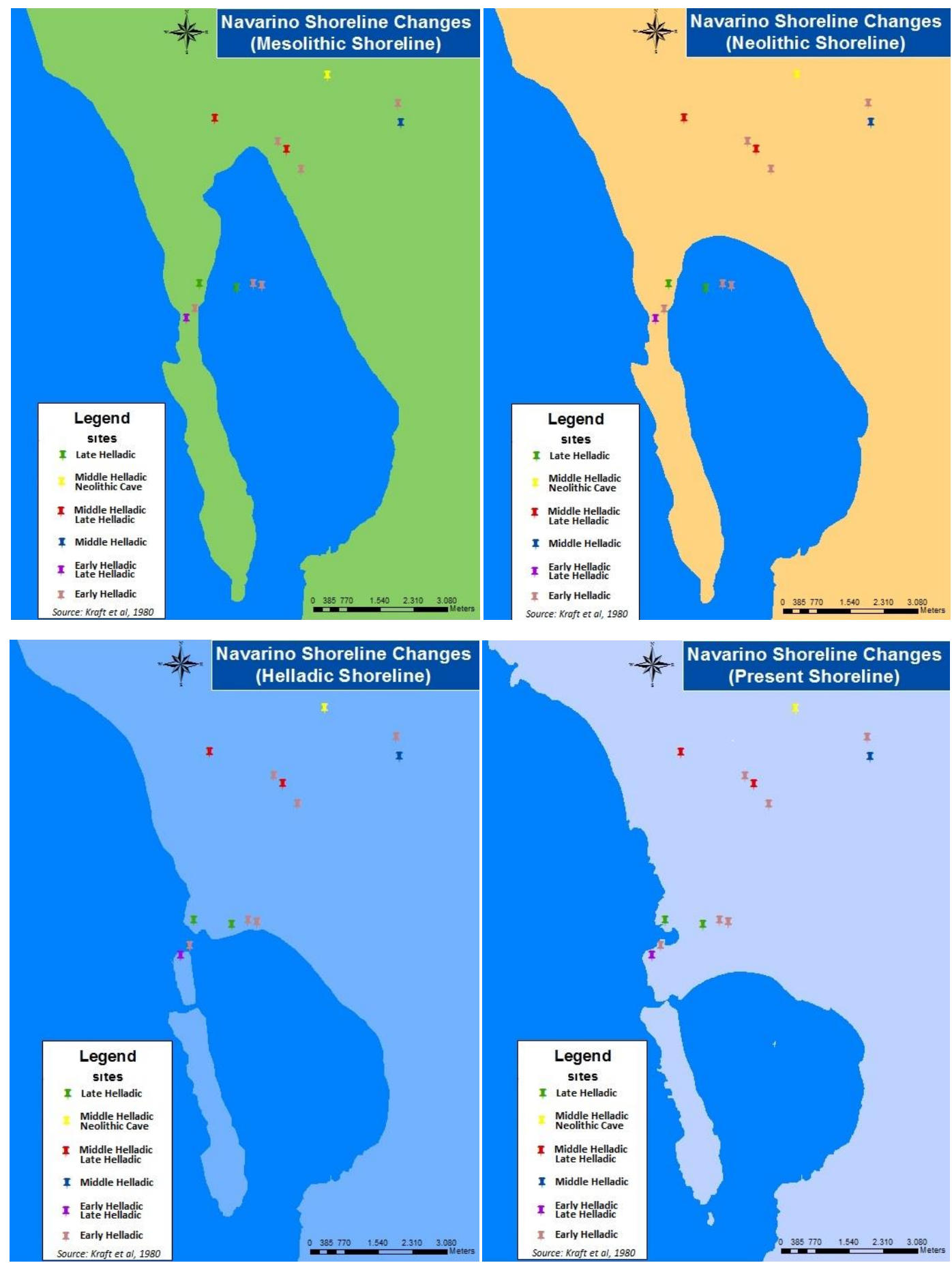

Figure 5. The four different changes of Navarino Bay shoreline, (a) the Mesolithic shoreline, (b) the Neolithic shoreline, (c) Helladic shoreline, (d) Present shoreline.

The methodology followed was based on existing maps and the purpose is not to give with absolute accuracy the change of shorelines through different time periods, as to present the methodological approach of creating multilevel information in GIS environment and also, the conditions of digitization of shorelines in a more general way. 


\section{Analysis and Results}

In order to understand the morphology of the area and the changes during different periods, Kraft and his team, examines the sedimentation processes of the surface and subsurface [17]. Subsurface sedimentation was interpreted using core logs from drill holes, as well as radiocarbon dating and pollen analyses. Paleogeographic reconstructions can be made based on the information from drill cores. The pollen data support the geological transition hypothesis by demonstrating the relative effects of the sedimentary environment on the pollen record.

According to radiocarbon dating drill-core sediments, $2.5 \mathrm{~km}$ north of the present sandy barrier of the coast, were dated at the Mesolithic time, where the north part of the area was a marine embayment dated back at 9.584 B.P. Swallow marine sediments were deposited at that time. Then, fluvial sedimentation of gravels, silts and stream sand from the "Amoudheri River", "Yialova River" and "Typhlomitis Creek" deposited their sediments, as well as "Xerias River" through sea transfer. Major early Holocene transgression have taken place during this time and was followed by a regression and ended at 8.951 BP. A late Holocene retreat followed a third transgression at $6983 \mathrm{BP}$ and a fourth at 4508 $\mathrm{BP}$. The most recent regression begins after $4508 \mathrm{BP}$, with the filling of the lagoon and the formation of the sea's sand barrier at $2745 \mathrm{BP}$, which still exists today. Radiocarbon sediment dating of the barrier implies a marine environment at $2745 \mathrm{BP}$, and that was an important factor for the reconstruction of the geography of the area of the Neolithic and Helladic times [10]. The last transgression is the sedimentation of the "Yialova lagoon", with the dating and elevation of the sediments showing Helladic inhabitation of the area. At the lagoon's edge, there are a number of Helladic sites that were utilized for semi-habitation and agricultural uses. At that time, "Sykia" channel was an open deep bay and "Voidokoilia" was an open channel at the north of the bay allowing a third marine entrance to the embayment. The northwest sand coast with the dunes was also present during the Helladic era. In addition, two Neolithic sites at the southeast edge of "Profitis Ilias" ridge, indicates habitation of the area. The east side wave-cut sea cliffs of Navarino bay were cut during this period. With variations in sea level and minor shoreline movements, the sand barrier existed by the time it was built and has survived to ourdays $[10,18]$.

\section{Conclusion}

Morphological and geological surface studies and subsurface stratigraphic analysis of the Holocene sediments were useful tools for the environmental reconstruction of the area. Significant changes occurred at the morphology of Navarino and the Ionian Sea over the past 9000 years. Sea regression started at 9500- 8900 BP., while people occupied the area without the presence of alluvial plain at the time. During Helladic era humans sheltered south of the plain and drainage it for agricultural purposes. Sand was moved along the Ionian Sea's shoreline, forming a sandy beach with dune fields.

In conclusion, the Yialova lagoon has 3 different phases of geomorphological evolution. The first phase, which lasted from 6500 to $6100 \mathrm{BC}$, was characterized by a swallow marine environment with a shoreline to the north. At the second phase, 6100-5800 years $\mathrm{BP}$, an alteration from a marine to a lagoon environment took place as a consequence to sand deposition and freshwater inflow from "Xerolagkados River". During the last phase, from 5800 to $3300 \mathrm{BP}$, the area is characterized as a Mediterranean lagoon that it is occurring until today $[2,10]$.

Geographic Information System (GIS) and paleoenvironmental analysis are powerful tools for archaeology and environmental researches. The case of Navarino bay in southwest Peloponnese and the Ionian Sea attracted the scientific attention through the morphological and geological changes during all known historical periods. A number of sci- 
entific articles are concerned about the area, and interdisciplinary approaches of the Navarino should be applied in order to exact new information and for a better understanding and interpretation of the area.

\section{References}

[1] Engel, M.; Knipping, M.; Brückner, H.; Kiderlen, M.; Kraft, J.C. “Reconstructing middle to late Holocene palaeogeographies of the lower Messenian plain (southwestern Peloponnese, Greece): Coastline migration, vegetation history and sea level change" Palaeogeography, Palaeoclimatology, Palaeoecology, 2009; 284, pp. 257-270

[2] Emmanouilidis, A.; Katrantsiotis, C.; Norstrom, E.; Risberg, J.; Kylander, M.; Sheik, T.A.; Iliopoulos, G.; Avramidis, P. “Middle to late Holocene palaeoenvironmental study of Yialova Lagoon, SW Peloponnese, Greece" Quaternary International, 2009; pp117.

[3] Mariolakos, I.; Ladas, I; "The evolution of the coastlines and the morphology of Pylia Peninsula (SW Peloponnesus, Greece) during the last 18.000 years" 8th Panhellenic Geographical Conference, Geomorphology, 2007; pp. 111-121.

[4] Kleman, J.; Borgström, I.; Alasdair, Skelton, A.; Hall, A.; “Landscape evolution and landform inheritance in tectonically active regions: The case of the Southwestern Peloponnese, Greece" Zeitschrift für Geomorphologie, 2016; 60(2) pp. 171-193.

[5] McDonald, W.A.; Simpson, R.H. "Prehistoric Habitation in Southwestern Peloponnese" American Journal of Archaeology, 1961; 65(3).

[6] McDonald, W.A.; Simpson, R.H. “Further Exploration in Southwestern Peloponnese: 1962-1963" American Journal of Archaeology, 1964; 68(3), pp. 229-245. doi:10.2307/502386

[7] McDonald, W.A.; Simpson, R.H. "Further Explorations in Southwestern Peloponnese: 1964-1968". American Journal of Archaeology, 1969; 73(2),

[8] Simpson, H.R. "Mycenaean Greece”, 1981; Park Ridge, New.

[9] Simpson, H.R. "Mycenaean Messenia and the Kingdom of Pylos", 2014; Philadelphia. INSTAP Academic Press, Pennsylvania.

[10] Kraft, J.C.; Rapp, G.R.; JR, Aschenbrenner, Jr “Late Holocene Palaeogeomorphic Reconstructions in the Area of the Bay of Navarino: Sandy Pylos", 1980; Journal of Archaeological Science, 7, pp 187-210.

[11] Reilly, P. "Towards a virtual Archaeology", at K. Lockyear / S. Rahtz, Computer Applications in Archaeology, British Archaeological Reports (Int. Series 565), Oxford 1990, pp.133-139.

[12] Malaperdas, G; Zacharias, N. “A Geospatial Analysis of Mycenaean Habitation Sites Using a Geocumulative versus Habitation Approach" Journal of Geoscience and Environment Protection, 2018; 6, pp. 111-131. https://doi.org/10.4236/gep.2018.61008

[13] Malaperdas, G.; Zacharias, N. “The habitation Model Trend Calculation (MTC): A new effective tool for predictive modeling in archaeology", Geo-spatial Information Science, 2019; DOI: 10.1080/10095020.2019.1634320

[14] Malaperdas, G. "Digitization in Archival Material Conservation Processes”, European Journal of Engineering and Technology Research, 2021; 6(4), pp. 30-32. doi: 10.24018/ejers.2021.6.4.2444.

[15] Malaperdas, G. "Practical Methods of GIS for Archaeologists: Spatial Division in a Large Area" SSRG International Journal of Geoinformatics and Geological Science, 2019; 6(1), 1-6. DOI: 10.14445/23939206/IJGGS-V6I1P101

[16] Worboys, M. “GIS: Breaking out of the box" Transactions in GIS, 1997; 2 (4), pp. 287-288.

[17] Kraft, J.C.; Rapp, G.; Jr. Aschenbrenner, J.S.E. “Late Holocene palaeogeography of the coastal plain of the Gulf of Messenia Greece and its relationships to archaeological settings and coastal change". Geological Society of America Bulletin, 1975; 86, pp.1191-1208.

[18] Avramidis, P.; Iliopoulos, G; Kontopoulos, N.; Panagiotaras, D.; Barouchas, P.; Nikolaou, K.; Papadopoulou, P. “Depositional environments, sediment characteristics, palaeoecological analysis and environmental assessment of an internationally protected shallow Mediterranean lagoon, Gialova Lagoon - Navarino Bay, Greece" Earth and Environmental Science Transactions of the Royal Society of Edinburgh, 2014, pp. 189-206. 